\title{
In Praise of Commercial Culture
}





\section{In Praise of}

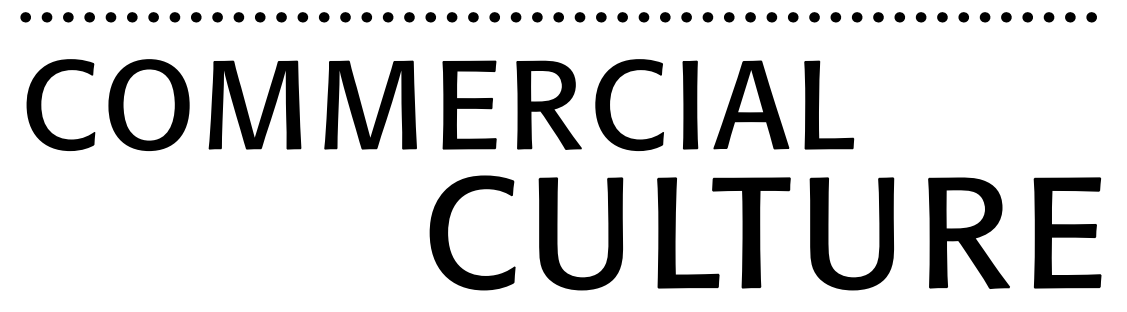

Tyler Cowen

HARVARD UNIVERSITY PRESS

Cambridge, Massachusetts

London, England 
Copyright (C) 1998 by the President and Fellows of Harvard College

All rights reserved

Printed in the United States of America

Second printing, 2000

First Harvard University Press paperback edition, 2000

Library of Congress Cataloging-in-Publication Data

Cowen, Tyler.

In praise of commercial culture / Tyler Cowen.

p. $\quad \mathrm{cm}$.

Includes bibliographical references and index.

ISBN 0-674-44591-0 (cloth)

ISBN 0-674-00188-5 (pbk.)

1. Arts-Marketing. 2. Arts and society. I. Title. NX634.C68 1998

$700^{\prime} .68^{\prime} 8-\mathrm{dc} 21$

$97-40445$ 